\title{
Ergonomic interventions in weeding operations for drudgery reduction of hill farm women of India
}

\author{
Jatinder Kishtwaria ${ }^{\mathrm{a}}$ and Aruna Rana ${ }^{\mathrm{b}}$ \\ a Prof. and Head, Department of Family Resource Management, College of Home Science, Himachal Pradesh \\ Agricultural University, Palampur, Himachal Pradesh, India 176062 \\ ${ }^{b}$ Research Associate, Department of Family Resource Management, College of Home Science, Himachal Pradesh \\ Agricultural University, Palampur, Himachal Pradesh, India 176062
}

\begin{abstract}
Weeding is an important time consuming and drudgery prone task mainly performed by hill farm women for almost all crops grown. This directs for interventions in terms of improved technologies (weeder, kutla and hoes) to relieve women from high energy demands, time spent and associated drudgery particularly for weeding activity. The study was conducted in two hill states of India viz. Himachal Pradesh (35 villages and 1500 representative samples) and Uttrakhand (10 villages and 500 representative samples). Experimental data were conducted on representative sub sample of 60 hill farm women of both states to assess physiological workload and musculo-skeletal problems both while working with traditional tools along with improved tools by employing selected parameters viz. physical fitness level, physiological parameters etc. The results showed that heart rate values were more than acceptable limits for task performed with the traditional tools as compared with improved tools. Significant reduction in the heart rate was observed while working with improved tools. Analysis of MSDs showed that the postural stress and severity of pain in various body parts was reduced by adopting new technology. Hence, the use of improved weeding tools is recommended over the existing ones for drudgery reduction.
\end{abstract}

Keywords: gender, agriculture, musculoskeletal disorders

\section{Introduction}

Women in India are major producers of food in term of value, volume and number of hours worked. [4]. Agriculture census of India (2001) has registered 25.68 percent of female population as workers. However, the female work participation rate has been reported higher in rural areas (30.98\%) as compared to urban areas (11.55\%). Amongst rural women workers, 81 per cent are employed in agriculture as labourers and cultivators [3]. Number of women as agriculture labourers (873) is more than the cultivators (478) [20].

Himachal Pradesh and Uttrakhand are small hill states of India in north western Himalaya, where agriculture is the mainstay of population due to low level of Industrialization. Inaccessibility, small and scattered land holdings are the main characteristics of hill agriculture due to which males generally migrate to plains to seek employment leaving all responsibilities including agriculture to women of family [8].

With the growing feminization of farm labour due to male rural to urban migration, women are forced to carry out work previously done by men. Consequently women are increasing their workload and taking care of a wider scope of agriculture tasks, but the degree to which they have access to improved technologies need special consideration [20]. It is true that at national level modernization of agriculture is taking place at a rapid pace, but women continue to perform farm operations which are full of drudgery while

Email: jkishtwaria@rediffmail.com

Tel.: +91 1894 230407, Mobile: +91 9418478407, Fax: +91 1894230511 
mechanized operations are performed by men [19]. In view of multiple and heavy worked of farm women, making available, simple, labour saving, cost effective, women friendly tools and implements for farm work would save millions of women from drudgery, stress and ill health. The technologies should fulfill the criterion of reduced workload, time spent, energy expended, stress, strains, body pains, fatigue and drudgery and in turn enhance efficiency, productivity, quality of produce, income and satisfaction of the farm women.

Weeding has been reported as maximum drudgery prone activity with a drudgery scale value of 2.01 followed by other agricultural operations as perceived by women [7]. Weeding by hand or using hand tools such as hand hoe and weeding hooks are widely used in rural India [13]. Weeding and intercultivation takes away 15 to $20 \%$ of total man hours involved in crop production [13]. An estimate of 400-600 man hours per hectare is the normal man hour requirement of hand weeding which amounts to Rs. 2200 per hectare which also depends upon weed infestation [23]. To get the full benefit of mechanization, it is very necessary to use proper weeding implements, which will reduce drudgery and cost of cultivation [17].

With this background it has emerged that suitability of tools and implements as per physical capacities of rural mountain women is lacking. Hence, present endeavor aims to develop women friendly technologies to alleviate them from backbreaking drudgery, pains and ill health and enhance productivity and efficiency in the weeding operations.

Thus, the study was undertaken with the following objectives:

1. To estimate the drudgery levels of farm women in various agricultural operations

2. To ascertain the health status of hill farm women

3. To assess the ergonomic cost of weeding with existing and improved technology.

\section{Methodology}

The study was conducted in two hill states of India viz. Himachal Pradesh and Uttrakhand in the following phases:

Phase I - Drudgery level assessment of farm women involved in various agricultural tasks

Phase II - Health status of hill farm women

Phase III - Ergonomic cost of weeding operations with existing and improved technology.

\section{Phase I- Drudgery level assessment of farm women involved in various agricultural tasks}

A survey was conducted in two hill states of India viz. Himachal Pradesh (35 villages and 500 representative sample) and Uttrakhand (10 villages and 500 representative sample) on a well-structured, pretested interview schedule. The data were analyzed to identify the drudgery prone tasks in agriculture on hierarchy basis by consolidating the different parameters viz. time expended on each task, frequency of activity performed and degree of difficulty experienced while doing the weeding operations by linear combination method. The coefficients of each activity were drawn on above three parameters to calculate the drudgery index as follows. 


$$
\text { Drudgery Index } \quad=\frac{X+Y+Z}{3} \times 100
$$

\section{Phase II-Health status of hill farm women}

Health status of farm women involved in drudgery prone activities was assessed using the following variables tools and techniques and formulae.

\begin{tabular}{|l|l|l|}
\hline Variables & Tools/Techniques & Formula \\
\hline Body weight (Kgs) & Weighing balance & - \\
\hline Body height (Cms) & Height measuring rod & - \\
\hline $\begin{array}{l}\text { Body Mass Index } \\
\text { (BMI) }\end{array}$ & - & $\begin{array}{l}\text { Weight }(\mathrm{kgs}) / \mathrm{Height}^{2} \\
(\mathrm{~cm})\end{array}$ \\
\hline $\begin{array}{l}\text { Physical Fitness } \\
\text { Index (PFI) }\end{array}$ & Step Stool Ergomaster & \\
\hline $\begin{array}{l}\text { Lean Body mass } \\
\text { (LBM) }\end{array}$ & Skin fold calipers & - \\
\hline $\begin{array}{l}\text { Oxygen } \\
\text { consumption }\end{array}$ & $\left(\mathrm{VO}_{2}\right.$ Max) & \\
\hline
\end{tabular}

\section{Interventions}

The existing tools were improved as per anthropometric data and physical fitness levels of hill women on ergonomic parameters. Three weeding tools were improved and introduced after modification viz. weeders, kutla and small hoe. These tools were made light in weight to ease the operation with suitable length, sharp inner edges and convenient handles.
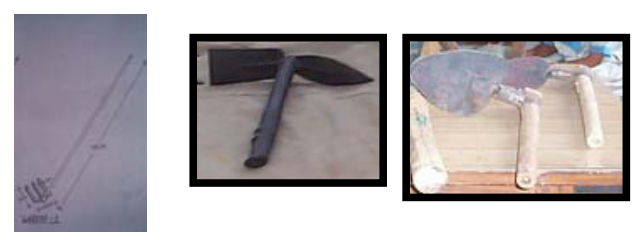

weeder Hoe

Kutla

Phase III Ergonomic cost of weeding operations with existing and improved technology.

Sixty healthy, non pregnant, hill farm women without major illness were selected for experiments to assess the ergonomic cost of weeding operations with existing and improved technology on following parameters
Statistical Analysis - Paired t-test was employed to find out the significant difference if any between existing practices and after adoption of improved

\begin{tabular}{|c|c|c|}
\hline Parameters & Tools/Techniques & Formula \\
\hline \multicolumn{3}{|l|}{ i)Physiological parameters } \\
\hline a) Heart Rate & $\begin{array}{ll}\begin{array}{l}\text { Polar Heart } \\
\text { Monitor } \\
\text { Monitor } \\
\text { Vantage mode) }\end{array} \\
\end{array}$ & - \\
\hline b) Energy Expenditure & - & $\begin{array}{l}0.159 * \text { average } \\
\text { heart rate- } 8.72\end{array}$ \\
\hline $\begin{array}{l}\text { c) Total Cardiac Cost of } \\
\text { Work (TCCW) }\end{array}$ & - & $\begin{array}{l}\text { Cardiac Cost of } \\
\text { Work }+ \text { Cardiac } \\
\text { Cost of Recovery }\end{array}$ \\
\hline $\begin{array}{ll}\text { d) } & \text { Physiological } \\
& \text { Cost of Work } \\
& \text { (PCW) }\end{array}$ & - & $\begin{array}{l}\text { TCCW/total time } \\
\text { of work }\end{array}$ \\
\hline \multicolumn{3}{|c|}{ ii) Psycho - Physiological parameters } \\
\hline $\begin{array}{l}\text { e) Rate of Perceived } \\
\text { Exertion }\end{array}$ & Borg's Scale & - \\
\hline \multicolumn{3}{|l|}{$\begin{array}{l}\text { iii) } \begin{array}{c}\text { Bio- mechanical } \\
\text { parameters }\end{array} \\
\end{array}$} \\
\hline $\begin{array}{ll}\begin{array}{c}\text { a)Musculo } \\
\text { problems }\end{array} & \text { Skeletal } \\
\end{array}$ & Human Body Map & - \\
\hline b) Postural analysis & Flexi curve & - \\
\hline c) Muscular strength & Grip dynamometer & $\begin{array}{l}\text { Strength of } \\
\text { muscles at rest- } \\
\text { strength of } \\
\text { muscles at work } \\
\text { /strength of } \\
\text { muscles at rest * } \\
100\end{array}$ \\
\hline \multicolumn{3}{|c|}{ iv) Environmental conditions } \\
\hline a) Temperature & Thermometer & - \\
\hline b) Relative humidity & Hygrometer & - \\
\hline v) Output parameters & \multicolumn{2}{|c|}{ Measuring tape / Weighing balance } \\
\hline
\end{tabular}
technologies by women in weeding operations

\section{Results}

Table 1

Physical characteristics and health status of the respondents

\begin{tabular}{lll}
\hline $\begin{array}{l}\text { Physical } \\
\text { Characteristics }\end{array}$ & \multicolumn{1}{c}{$\begin{array}{c}\text { Himachal } \\
\text { Pradesh }\end{array}$} & Uttrakhand \\
\cline { 2 - 3 } & \multicolumn{2}{c}{ Mean } \\
\hline Age (Yrs) & 35.8 & 36 \\
\hline Height $(\mathrm{cm})$ & 152.4 & 154 \\
\hline Weight $(\mathrm{kg})$ & 53.01 & 47.5 \\
\hline L B M (kg) & 27.85 & 24.4 \\
\hline B M I & 22.85 & 20.17 \\
\hline
\end{tabular}




\begin{tabular}{lll}
\hline $\mathrm{VO}_{2} \mathrm{Max}$ & 25.35 & 32.08 \\
\hline
\end{tabular}

Health status of farm women of the two hill states was ascertained in terms of LBM, BMI and Vo2 max. The average age of women of Himachal Pradesh was 35.8 years having an average height of $152.4 \mathrm{~cm}$, weight $48.73 \mathrm{~kg}$ with a BMI of 22.85 whereas women of Uttrakhand were in the average age group of 36 years with a height of $154 \mathrm{~cm}$ and $47.5 \mathrm{~kg}$ of body weight. Physical fitness level of majority of respondents was found to be high average followed by good (Table 1).

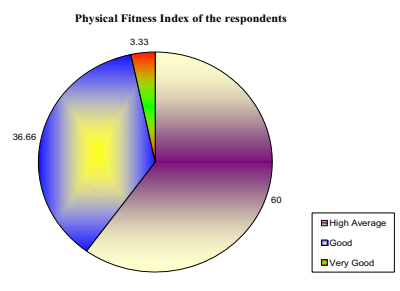

Table 2

Drudgery Index of various agricultural operations undertaken by hill farm women

\begin{tabular}{|lll|}
\hline Activities & $\begin{array}{l}\text { Himachal } \\
\text { Pradesh }\end{array}$ & Uttrakhand \\
\cline { 2 - 3 } & Drudgery Index \\
\hline Transplanting & 71 & 34.66 \\
\hline $\begin{array}{l}\text { Transportation of } \\
\text { manure }\end{array}$ & 61.6 & 52.33 \\
\hline Weeding & 37.3 & 31.33 \\
\hline Spreading of manure & 35 & 28.00 \\
\hline $\begin{array}{l}\text { Removing of stalks } \\
\text { and stubble }\end{array}$ & 31 & - \\
\hline $\begin{array}{l}\text { Cleaning of farm } \\
\text { produce }\end{array}$ & - & 26.26 \\
\hline
\end{tabular}

After drawing coefficients of difficulty score, performance score and time score by linear combination method, the drudgery index calculated was maximum for transplanting, transportation of manure followed by weeding and spreading of manure amongst various agricultural tasks carried out by hill farm women (Table 2).

Table 3a

Ergonomic cost of work of women while performing the weeding operations using existing and improved tools

\begin{tabular}{|c|c|c|c|c|c|c|c|c|}
\hline \multirow[t]{3}{*}{$\begin{array}{l}\text { Para } \\
\text { meters }\end{array}$} & \multirow{2}{*}{\multicolumn{2}{|c|}{$\begin{array}{l}\text { Himachal } \\
\text { Pradesh } \\
\text { Traditi Weeder } \\
\text { onal }\end{array}$}} & \multicolumn{4}{|c|}{ Uttranchal } & \multicolumn{2}{|c|}{$\begin{array}{l}\text { Significant } \\
\text { change }\end{array}$} \\
\hline & & & \multicolumn{2}{|c|}{ Traditional } & \multicolumn{2}{|c|}{ Improved } & \multirow{2}{*}{$\begin{array}{c}\text { Hima } \\
\text { chal } \\
\text { Prade } \\
\text { sh } \\
\end{array}$} & \multirow{2}{*}{$\begin{array}{c}\text { Uttr } \\
\text { akh } \\
\text { andl }\end{array}$} \\
\hline & & & 1 & 2 & Kutla & $\begin{array}{l}\text { Small } \\
\text { Hoe }\end{array}$ & & \\
\hline \multicolumn{9}{|c|}{ Physiological and Psycho-physiological parameters } \\
\hline $\begin{array}{l}\text { Average } \\
\text { workin } \\
\text { g heart } \\
\text { rate } \\
\text { (b/min) }\end{array}$ & 109 & 106 & 93 & 103 & 89 & 99 & $1.72 *$ & $\begin{array}{l}1.79 *_{-} \\
\text {Kutla } \\
1.74 *_{-} \\
\text {Small } \\
\text { Hoe }\end{array}$ \\
\hline $\begin{array}{l}\text { Average } \\
\text { energy } \\
\text { expendi } \\
\text { ture } \\
(\mathrm{kj} / \mathrm{min})\end{array}$ & 8.58 & 8.11 & 6.09 & 7.70 & 5.37 & 6.97 & - & - \\
\hline $\begin{array}{c}\text { Average } \\
\text { TCCW } \\
\text { (beats) }\end{array}$ & 600 & 607 & 456 & 194 & 296 & 283 & - & $\begin{array}{l}2.57^{*}- \\
\text { Kutla } \\
0.166- \\
\text { Small } \\
\text { Hoe }\end{array}$ \\
\hline $\begin{array}{c}\text { Average } \\
\text { PCW } \\
\text { (b/min) }\end{array}$ & 20 & 20.2 & 45.6 & 19.4 & 29.6 & 28.3 & - & \\
\hline $\begin{array}{l}\text { Average } \\
\text { RPE }\end{array}$ & 4 & 3 & 4 & 3 & 2 & 1 & $5.05^{*}$ & $\begin{array}{l}7.07 *_{-} \\
\text {Kutla } \\
2.84 *_{-} \\
\text {Small } \\
\text { Hoe }\end{array}$ \\
\hline
\end{tabular}

The findings of ergonomic assessment for the traditional /improved tools under the study showed that heart rate values were more than acceptable limits while weeding with the traditional tool $(93 \mathrm{bpm}$ and $103 \mathrm{bpm}$ ). The comparative assessment between use of traditional vs. improved tools in both the states showed better results in terms of heart rate values (kutla -89 bpm, small hoe - 99bpm) (Table 3a). Similar trend was observed in the total cardiac cost of work and the physiological cost of work. Significant changes in the heart rate $(1.79 *$ - Kutla, 1.74* - small hoe), TCCW (2.57* - Kutla) and RPE (7.07* - Kutla, 2.84* - small 
hoe) were observed while carrying out the weeding task with the improved tools.

Table $3 b$

Assessment of bio-mechanical stresses of women while performing the weeding operations using existing and

\begin{tabular}{|c|c|c|c|c|c|c|}
\hline \multirow[t]{3}{*}{ Parameters } & \multicolumn{2}{|c|}{$\begin{array}{c}\text { Himachal } \\
\text { Pradesh }\end{array}$} & \multicolumn{4}{|c|}{ Uttrakhand } \\
\hline & \multirow{2}{*}{\multicolumn{2}{|c|}{$\begin{array}{l}\text { Traditio Weeder } \\
\text { nal }\end{array}$}} & \multicolumn{2}{|c|}{ Traditional } & \multicolumn{2}{|c|}{ Improved } \\
\hline & & & 1 & 2 & Kutla & $\begin{array}{l}\text { Small } \\
\text { Hoe }\end{array}$ \\
\hline \multicolumn{7}{|c|}{ Grip strength } \\
\hline Right & 11.8 & 8.33 & 33.33 & 16.66 & 25.00 & - \\
\hline Left & 12 & 10.2 & 33.33 & 20.00 & 12.5 & 14.28 \\
\hline $\begin{array}{l}\text { Angle of } \\
\text { normal } \\
\text { curve }\left({ }^{\circ}\right)\end{array}$ & 192.3 & 192.6 & 187 & 190 & 187 & 190 \\
\hline $\begin{array}{l}\begin{array}{l}\text { Angle of } \\
\text { bend }\left({ }^{\circ}\right)\end{array} \\
\end{array}$ & 198 & 191.38 & 190 & 188 & 186 & 180 \\
\hline $\begin{array}{l}\text { Angle of } \\
\text { deviation } \\
\left({ }^{\circ}\right)\end{array}$ & 5.75 & 2.1 & -7 & -3 & 5 & - \\
\hline
\end{tabular}

The hand muscles were less fatigued with the use of improved tools (Table $3 b$ ). The new improved tools for weeding were able to lessen the angle of deviation, improve posture and lessen fatigue.

Table 3c

Musculo Skeletal Problems of women while working with the tools

\begin{tabular}{|c|c|c|c|}
\hline \multirow[t]{2}{*}{ Activities } & \multirow[t]{2}{*}{ Tools Used } & $\begin{array}{c}\text { Himachal } \\
\text { Pradesh }\end{array}$ & Uttrakhand \\
\hline & & \multicolumn{2}{|c|}{ Musculo Skeletal Problems } \\
\hline \multirow{5}{*}{ Weeding } & $\begin{array}{l}\text { Traditional } \\
\text { Tool/Method }\end{array}$ & - & $\begin{array}{l}\text { Very severe pain } \\
\text { in shoulder and } \\
\text { severe pain in } \\
\text { upper back }\end{array}$ \\
\hline & Kutla & - & $\begin{array}{l}\text { Mild pain in } \\
\text { upper back }\end{array}$ \\
\hline & $\begin{array}{l}\text { Traditional } \\
\text { Tool/Method }\end{array}$ & - & $\begin{array}{l}\text { Severe pain in } \\
\text { low back and } \\
\text { thighs }\end{array}$ \\
\hline & Small Hoe & - & $\begin{array}{l}\text { Mild pain in } \\
\text { wrists and hands }\end{array}$ \\
\hline & $\begin{array}{l}\text { Traditional } \\
\text { Tool/Method }\end{array}$ & $\begin{array}{l}\text { Severe pain } \\
\text { in low back, }\end{array}$ & - \\
\hline
\end{tabular}

\begin{tabular}{|ll|}
\hline & $\begin{array}{l}\text { thighs and } \\
\text { feet }\end{array}$ \\
\cline { 2 - 3 } & Mild pain in - \\
low back
\end{tabular}

Weeding was perceived as very heavy task resulting into severe to very severe body pains and MSD problems. The use of traditional tools by the farm women led to the development of various musculo skeletal problems like severe pain in back and thighs. The pain still persisted while working with the improved tools that is kutla, hoe and weeder but the severerity was reduced to a great extent. (Table 3c)

Table $3 b$

Production output and environmental parameters while weeding by existing and improved tools

\begin{tabular}{|c|c|c|c|c|c|c|c|c|}
\hline \multirow[t]{3}{*}{$\begin{array}{l}\text { Parame } \\
\text { ters }\end{array}$} & \multicolumn{2}{|c|}{$\begin{array}{c}\text { Himachal } \\
\text { Pradesh }\end{array}$} & \multicolumn{4}{|c|}{ Uttrakhand } & \multicolumn{2}{|c|}{$\begin{array}{l}\text { Significant } \\
\text { change }\end{array}$} \\
\hline & \multirow[t]{2}{*}{$\begin{array}{l}\text { Tradit } \\
\text { ional }\end{array}$} & \multirow[t]{2}{*}{$\begin{array}{l}\text { Impro } \\
\text { ved }\end{array}$} & \multicolumn{2}{|c|}{$\begin{array}{l}\text { Traditio } \\
\text { nal }\end{array}$} & \multicolumn{2}{|c|}{ Improved } & \multirow{2}{*}{$\begin{array}{c}\text { Himac } \\
\text { hal } \\
\text { Prad } \\
\text { esh }\end{array}$} & \multirow[t]{2}{*}{$\begin{array}{c}\text { Uttrak } \\
\text { hand }\end{array}$} \\
\hline & & & 1 & 2 & $\begin{array}{l}\text { Kutl } \\
\text { a }\end{array}$ & $\begin{array}{l}\text { Small } \\
\text { Hoe }\end{array}$ & & \\
\hline \multicolumn{9}{|c|}{ Output parameters } \\
\hline $\begin{array}{l}\text { Coverage } \\
\text { of land } \\
\text { under } \\
\text { operation } \\
\text { (sq. mt.) }\end{array}$ & 46.03 & 77.1 & 70.1 & 58. & 198.9 & 70.4 & $8.34^{*}$ & $\begin{array}{l}6.70^{*}- \\
\text { Kutla } \\
4.76^{*}- \\
\text { Small } \\
\text { Hoe }\end{array}$ \\
\hline \multicolumn{9}{|c|}{ Environmental parameters } \\
\hline $\begin{array}{l}\text { Mean } \\
\text { Ambient } \\
\text { tempera } \\
\text { ture }\left({ }^{C}\right)\end{array}$ & $26^{\circ} \mathrm{C}$ & $27^{\circ} \mathrm{C}$ & $\begin{array}{l}25 \\
{ }^{\circ} \mathrm{C}\end{array}$ & $\begin{array}{l}25 \\
{ }^{\circ} \mathrm{C}\end{array}$ & $\begin{array}{l}26^{\circ} \\
\mathrm{C}\end{array}$ & $26^{\circ} \mathrm{C}$ & \multirow{2}{*}{\multicolumn{2}{|c|}{$\begin{array}{l}\text { Comfortable } \\
\text { temperature } \\
\text { within acceptable } \\
\text { limits }\end{array}$}} \\
\hline $\begin{array}{l}\text { Mean } \\
\text { Relative } \\
\text { Humidity } \\
(\%) \\
\end{array}$ & $62 \%$ & $68 \%$ & $57 \%$ & $\begin{array}{l}60 \\
\%\end{array}$ & $\begin{array}{l}59 \\
\%\end{array}$ & $58 \%$ & & \\
\hline
\end{tabular}

The experiments were conducted for 30 minutes while working with both traditional and improved tools each to elicit differences if any in production output in both the states. The results revealed that the coverage of land under operation in case of improved treatments (tools) was more as compared to the existing condition in both the states i.e. Himachal Pradesh (Existing tools - 46.03 sq.mt; Improved tool- 77.1 sq.mt.) and Uttrakhand (Existing tools -70.1 sq.mt and 58.1 sq.mt.; Kutla -98.9 sq.mt. and small hoe -70.4 sq.mt.). Use of improved tools showed significant increase in the coverage of land under operation (kutla - 8.34*, 4.76* 
Small hoe). Improved technologies gave better output than the traditional technologies

\section{Discussions}

Agriculture remains the key source of livelihood for India, more so in hill states of Himachal Pradesh and Uttrakhand where traditional farming operation is a complex product of diversified production systems and hill women are repository of knowledge (local techniques and technologies) that has evolved over a long period of time. Drudgery index calculated for weeding was ranked as one of the most laborious drudgery prone [5] and time consuming [13] activity in both the states (Table 2)

Physical fitness level of majority of respondents was high average depicted through PFI, BMI, and VO2 Max results (Table 1). The identification of occupational health hazards and decreased MSD requires occupational health related knowledge in agricultural tasks performed by women. [21].

Weeding was perceived as very heavy task resulting into severe to very severe body pains and MSD problems [22]. The physical strain, fatigue and drudgery might result in accidents and therefore, work levels for 8 hourly activities for both men and women should not exceed beyond 35 and $28 \%$ of one's aerobic capacity [14].

Studies of agricultural safety and health document that agricultural work involves risk factors associated with MSDs [11] endemic and highest priority throughout the agricultural tasks [9]. The arduous operation of weeding is usually performed manually with use of traditional hand tools in upright bending posture inducing back pain for majority of farmers women (Table 3 ) $[23,25]$. In traditional farming, there are concerns related to drudgery, slow pace of work, primitive tools and methods where ergonomics might bring solutions by contributing to the work efficiency and productivity justified factors. eg weeders, hoes etc [15].

Research has shown that many important risk factors can be successfully addressed in agricultural work using ergonomic approaches. [13]. Addressing these risk factors effectively requires interventions which are acceptable to farm women and have significant preventive impact. Analysis of physiological parameters in terms of working heart rate values [18]; human energy expenditure (Table 3a) [14] determines job severity assessing tools, work methods etc. to reorganize the work [16, 24]. Respondents perceived fatigue which was a subjective feeling and reliable indicator for assessment of workload $[2,16]$ (Table 3a).

Designing of tools and equipments and work processes with due consideration of ergonomical characteristics of women are accommodating to prevent MSDs. (Table 3b). Reviewed literature suggests that many important risk factors and health problems can be successfully addressed in agricultural work using ergonomic approaches. Therefore, ergo design alternatives might be perceptible in terms of health, comfort and can be integrated and tailored in the line of ILO proposed occupational safety and health (OSH) management system [21].

Improved technologies gave a better output than the traditional technologies and more area was covered thereby, significant increasing the input output ratio [8] (Table 3d).

\section{Conclusion}

- Role of women in agriculture is increasingly understood and recognized.

- Women have different ergonomical characteristics than men; therefore, design of women friendly tools and equipments is required.

- There is a need of more applied research in the field of agricultural health and safety for women farmers.

- Significant changes were observed in the physiological parameters and musculo skeletal problems faced by women farmers while working with the improved tools as compared to the existing tool.

- Hence, it may be concluded that new/improved technologies used in weeding are significant contribution in reducing drudgery and improving the output and satisfaction of rural masses.

- There is a need to have national policy on occupational health in agriculture to empower farm women in reducing drudgery, increasing 
safety, productivity, efficiency and well being of farm women.

\section{References}

[1] Badiger C, Hasalkar S, Huilgol S, Hosakeri M, Kavita P., Ergonomic assessment of improved agricultural technologies introduced for farm women in Northern Karnataka, Power Machinery Systems and Ergonomics, Safety and Health. (2004) pp. 321-325.

[2] Borg, G. Psychological basis of physical exertions, Medicine and Science in sports, 14, 1982, pp. 377-381.

[3] Census of India, National Commission for Women, New Delhi, 2001.

[4] Dash B, Role of Women in Agriculture, Ergonomics and Musculoskeletal Injuries in Agriculture: Recognizing and Preventing the Industry's Most Widespread Health and Safety Problem. Yojna, Vol-44(II), 2000, pp. 35-37.

[5] Gopikuttan G, Kurup KNP. Paddy land conversion in Kerala: An inquiry into ecological and economic aspects in a midland watershed region. Kerala research Programme on local level development, centre for development studies, 2004 Thiruvananthapuram.

[6] G.S. Ogato, E.K. Boon and J.Subramani, Gender Roles in Crop Production and Management practices: A case study of three rural communities in Ambo district, Ethopia. Journal of human Ecology Vol:27(1), 2009.

[7] Gupta p, Singhal A, Singh S, Sharma P and Jain S. Drudgery faced by farm women in agriculture. National Seminar on Dynamics of Women in Agriculture for National Development (2002) M.P. University of Agriculture and technology, Udaipur, India.

[8] Kishtwaria, J. and Rana, A., Drudgery of hill farm women due to weeding activity- some solutions, Women at work, Vol. II, Allied Publishers Ltd. (2007), pp. 43-49.

[9] Meyers, J., Miles, J., Faucett, J., Janowitz, I., Tejeda, D., Weber, E., Smith, R. and Garcia, L., Ergonomics risk factors for musculo skeletal disorder in wine grape vineyard work. Paper presented at National Institute for farm safety, Winnepeg, Canada, 1998.

[10] MM Pandey, Status of farm mechanization in India, Present status and future requirements of farm equipment for crop production

[11] Murphy, D., Safety and health for production agriculture, St. Joseph, MO ASAE, 1992
[12] Oberoi K. and Singh O.P., All India Coordinated Research Project in Home Science: Annual Report 2001, New Delhi, India.

[13] PK Nag and A Nag, Drudgery, Accidents and injurious in Indian Agriculture, Industrial Health (2004), 42.149-162

[14] PK Nag and Chatterjee SK, Physiological reactions of female workers in Indian agricultural work. Human factors (1980) 23,607-614.

[15] PK Nag, Sebastian NC and Malvankar MG, Occupational workload of Indian agricultural workers. Ergonomics (1980)23,91-102.

[16] Rao,S., Physiological costs and perceived exertion for home and farm activities done by rural women. Ph.D. Dissertation, SNDT Women's University Mumbai, 1987.

[17] R. Remesan ,M.S Roopesh, N.Remya and P.S. Preman, 2007” Wet Land Paddy Weeding - A Comprehensive Comparative Study from South India". Agricultural Engineering International: the CIGR E Journal. Manuscript PM 07011.Vol.IX.

[18] Sawakar, S.P., Vargese, MA, Saha PN and Ashalatha, KV. Ergonomic Assessment of Occupational workload and rest allowances for female agriculture labourers in Dharwad Karnataka. In proceedings of conference on humanizing work and work environment.(2001) pp140-144.

[19] Singh, G., Equipment to ensure timeliness, The hindu survey of Indian agriculture, M/S Kasturi and sons Ltd, Chennai, 2002, pp. 195-198.

[20] Suman Agarwal, Gender involvement in Farm Mechanization Issues for Extension and Research. NRC for Women in Agriculture, Bhubneshwar, India.Gite Vol.II, (2007) p 51.

[22] Surbhi Singh and Renu Arora, Ergonomic intervention for preventing musulo skeletal disorders among farm women, J.Agri. Sci. 1(2), 2010, pp. 61-71.

[23] Swapnali Borah, Firewood collection: A back breaking work for tribal farm women, Women at work, Vol. II, Allied Publishers Ltd., 2007, pp. 132-138.

[24] Tajuddin A. Advances in mechanical method of weed management agro ecological context studies in Agronomy studies in TNAU, Coimbatore, 1996

[25] Tewari R. Participation of women in fisheries, Ph.D. Thesis, SNDT Women's University, Mumbai, India. 1994

[26] Veerangounda M, Sushilendra ER and Anantachar M. Performance evaluation of weeders in cotton. Karanataka Journal of Agric. Sci. (2010) 23(5): pp 732-736. 